\title{
Tipologi Korupsi Serta Penanganan yang Berkepastian Hukum dan Keadilan
}

\section{Yusrizal $^{1}$}

Dosen Fakultas Hukum Universitas Malikussaleh

Ketua Bagian Hukum Pidana Fakultas Hukum Universitas Malikussaleh

yusrizal_mh@yahoo.com

\begin{abstract}
The concept of state law (rechtstaat) relating to corruption case has to be conducted by implementing law enforcement, law certainty, and justice. Any kind of policy in relation with corruption eradication has tobe done based on the application of legislation. The rule of legal officers in eradicating corruption is highly influenced by integrity of morality and personal ethic (the maturnity of spiritual intelligence) by having good understanding on corruption eradication which is very significance in making decision in relation with corruptor.
\end{abstract}

Keywords:

Corruption, Law Certainty, Justice

\begin{abstract}
Abstrak
Konsep negara hukum (rechtstaat) terhadap tindak pidana korupsi harus dimulai dari penegakan hukum yang berkepastian dan keadilan artinya segala sesuatu yang berupa kebijakan dalam penanganan serta pemberantasan korupsi seyogiyanya berdasarkan hukum yang berlaku. Peranan aparat penegak hukum dalam menberantas korupsi sangat dipengaruhi oleh moral dan etika yang berintegritas (pembangunan kecerdasan spiritual), dengan pemahaman budaya hukum atas pembersihan korupsi tersebut. Disinilah letak kebijaksanaan dalam pengambilan keputusan terhadap koruptor.
\end{abstract}

Kata Kunci:

Korupsi, Kepastian Hukum, Keadilan 


\section{A. PENDAHULUAN}

$$
\text { Pasal } 1 \text { ayat (3) Undang- }
$$

Undang Dasar 1945 menyebutkan

"Negara Indonesia adalah negara

hukum". Hal ini mengandung makna bahwa didalam Negara Kesatuan Republik Indonesia (NKRI) hukum merupakan "panglima" dan urat nadi pada segala aspek kehidupan bernegara maupun bermasyarakat. Hukum sebagai suatu sistem mempunyai peran yang strategis dan dominan. Menurut L.M. Friedman, 1 hukum sebagai suatu sistem akan dapat berperan dengan baik di dalam masyarakat jika instrumen pelaksanaannya dilengkapi dengan kewenangan-kewenangan di bidang penegakan hukum.

Sistem hukum tersebut tersusun dari subsistem hukum yang berupa: substansi hukum, struktur hukum dan budaya hukum. Ketiga unsur sistem hukum inilah yang sangat menentukan apakah suatu suatu sistem hukum bekerja atau

\footnotetext{
* Artikel ini pernah Disampaikan dalam Bimbingan Teknis Advokasi Perkara Hukum Aparatur Pemerintah Tahun 2015 di Aula BAPPEDA Kabupaten Bireuen, Tgl. 8 Juni 2015.

${ }^{1}$ L.M Friedman, The Legal System: A Social Science Perspective, (New York Russel Sage Foundation, 1975), hlm. 11, dan Vide Moh. Hatta, Beberapa Masalah
}

tidak. Substansi hukum biasanya terdiri dari berbagai himpunan peraturan perundang-undangan. Sedangkan struktur hukum adalah aparat penegak hukum, sarana dan prasarana hukum. Adapun budaya hukum adalah berupa perilaku hukum dari para anggota masyarakat itu sendiri. $^{2}$

Begitu pula dalam penanganan berbagai kasus korupsi, maka hukum harus ditegakkan sebagaimana yang digariskan oleh hukum. Penegakan hukum selalu melibatkan manusia didalamnya dan melibatkan juga tingkah laku manusia. Hukum tidak dapat tegak dengan sendirinya, artinya hukum tidak mampu mewujudkan sendiri janji-janji serta kehendakkehendak yang tercantum dalam (peraturan-peraturan) hukum. Janji dan kehendak tersebut, misalnya untuk memberikan hak kepada seseorang, mengenakan pidana terhadap seorang yang memenuhi persyaratan tertentu dan sebagainya. ${ }^{3}$

Penegakan Hukum Pidana Umum dan Pidana Khusus, (Yogyakarta: Liberty Yogyakarta, 2009), hlm. 1

${ }^{2}$ Ibid, hlm. 1

${ }^{3}$ Satjipto Rahardjo, Penegakan Hukum Suatu Tinjauan Sosiologis, (Yogyakarta: Genta Publishing, 2009), hlm. 7 
Terjadinya musibah dalam kehidupan hukum di Indonesia pada akhir-akhir ini, seperti peradilan terhadap para hakim dan penyalahgunaan kekuasaan dalam hukum oleh aparat penegak hukum serta friksi yang timbul dalam masyarakat sebagai akibat pelaksanaan penegakan hukum, tampaknya tidak harus dikembalikan kepada masalah mentalitas para pelaksana penegakan hukum, sebagaimana lazimnya dilontarkan masyarakat, melainkan juga ada kemungkinan disebabkan oleh karena memang nilai (keadilan) yang terkandung dalam peraturan perundang-undangan yang berlaku dewasa ini sudah jauh dari memadai, bahkan bertentangan dengan pendapat dan rasa keadilan masyarakat kita. ${ }^{4}$

$\begin{array}{rlr} & \text { Berkaitan } & \text { dengan kepastian } \\ \text { hukum dan keadilan dalam }\end{array}$
penanganan perkara dugaan tindak pidana korupsi, syarat pertama untuk menindak suatu perbuatan tercela yaitu adanya suatu ketentuan didalam

\footnotetext{
${ }^{4}$ Ibid, hlm. 69

5 Teguh Prasetyo dan Abdul Halim Barkatullah, Politik Hukum Pidana Kajian Kebijakan Kriminalisasi dan Dekriminalisasi, (Yogyakarta: Pustaka Pelajar, 2005), hlm. 26
}

undang-undang pidana yang merumuskan perbuatan tercela itu memberikan suatu sanksi terhadapnya atau disebut dengan legalitas hukum. ${ }^{5}$ Konsep bahwa tindak pidana adalah melanggar kepentingan negara sebagai reperesentasi kepentingan publik, umumnya menjadi dasar kewenangan negara untuk menentukan, membuat peraturan, menuntut, dan menghukum seseorang yang melanggar peraturan. Hal ini ini diperkuat oleh pengklasifikasian ilmu hukum, dimana hukum pidana adalah bagian dari hukum publik yang tidak membolehkan campur tangan individu. ${ }^{6}$

Dalam penanganan perkara korupsi sering muncul antara perilaku menegakkan hukum dengan menggunakan hukum sulit dibedakan. Kebetulan, keduanya memang saling melengkapi. Menegakkan hukum tanpa menggunakan hukum dapat melahirkan tindakan sewenangsewenang (abuse de droit). Sebaliknya, bila menggunakan hukum tanpa

${ }^{6}$ Ibid, hlm. 26, dan Vide Yusrizal, Asas Legalitas Dalam Sistem Hukum Pidana Di Indonesia, Dalam Jurnal Reusam Fakultas Hukum Universitas Malikussaleh, Vol. 1 No. 2 November 2013, hlm. 17 
berniat menegakkan hukum dapat menimbulkan ketidakadilan, bahkan dapat membawa keadaan seperti tanpa hukum (lawless). Polisi, jaksa, hakim, advokat, birokrat, politisi, dan siapa saja yang berkecimpung dalam dunia penegakkan hukum akan merasakan himpitan paradoks tersebut. Mereka senantiasa ditantang untuk menyeimbangkan dua kutub, antara menegakkan hukum dan menggunakan hukum.7 Untuk itulah dibutuhkan keseimbangan dalam melakukan penegakan hukum, khususnya menegakkan hukum pidana yang berkaitan dengan korupsi.

\section{B. PERMASALAHAN}

Berkaitan dengan latar belakang diatas maka yang menjadi permasalahan adalah mengenai proses penegakan hukum terhadap pemberantasan korupsi yang berkeadilan dan berkepastian hukum di Indonesia.

\section{METODE PENELITIAN}

Metode penelitian yang digunakan dalam penulisan artikel ini adalah penelitian yang bersifat yuridis

7 Tb. Ronny Rahman Nitibaskara, Tegakkan Hukum Gunakan Hukum, (Jakarta: Kompas, 2006), hlm. xii normatif, yaitu dengan mengkaji/menganalisis data sekunder yang berupa bahan-bahan hukum terutama bahan hukum primer dan bahan hukum sekunder dengan memahami hukum sebagai seperangkat peraturan atau normanorma positif di dalam sistem perundang-undangan yang mengatur mengenai kehidupan manusia. 8

Adapun bahan hukum yang digunakan dalam menyusun penulisan ini diperoleh dari penelitian kepustakaan (library research), sebagai suatu teknik pengumpulan bahan hukum dengan memamfaatkan berbagai literatur berupa aspek-aspek hukum di Indonesia, peraturan perundang-undangan, buku-buku, karya ilmiah, bahan kuliah, serta sumber bahan hukum sekunder lain yang mendukung dalam penulisan ini.

\section{PEMBAHASAN}

\section{Pengertian Korupsi}

Dilihat dari segi peristilahan, kata korupsi berasal dari bahasa latin corruptio yang berasal dari corrumpere suatu kata latin yang lebih

8 Mukti Fajar Nur Dewata dan Yulianto Achmad, Dualisme Penelitian Hukum Normatif dan Empiris, (Yogyakarta, Pustaka Pelajar, 2010), hlm. 34 
tua atau menurut Webster student dictionary adalah corruptus. Dari bahasa latin tersebut turun ke banyak bahasa di eropa seperti di Inggris: corruption-corrupt, Perancis: corruption, Belanda: corruptie (korruptie). Dapat diduga bahwa istilah korupsi di Indonesia berasal dari bahasa Belanda yang kemudian di adopsi menjadi korupsi., Malaysia menyebut korupsi sebagai riswah/risywah. ${ }^{9}$

Mengenai pengertian korupsi seperti yang disimpulkan dalam Encyclopedia Americana, korupsi itu adalah suatu hal yang bermacammacam artinya, bervariasi menurut waktu, tempat dan bangsa. Korupsi adalah kejahatan yang luar biasa (extra ordinary crime) atau perbuatan yang teramat jahat (the root of all evils). ${ }^{10}$

\section{Berdasarkan peristilahan korupsi yang berasal dari kata "corruptio" dalam bahasa Latin yang berarti kerusakan atau kebobrokan, dan dipakai pula untuk menunjuk suatu keadaan atau perbuatan yang}

\footnotetext{
${ }^{9}$ Dani Krisnawati, dkk, Bunga Rampai Hukum Pidana Khusus, (Jakarta: Pena, 2006), hlm. 35-36
}

10 Ibid, hlm. 37 busuk. Dalam perkembangan selanjutnya, istilah ini mewarnai perbendaharaan kata dalam bahasa berbagai negara, termasuk bahasa Indonesia. Istilah korupsi yang sering dikaitkan dengan ketidakjujuran atau kecurangan seseorang dalam bidang keuangan. Dengan demikian, melakukan korupsi berarti melakukan kecurangan atau penyimpangan menyangkut keuangan negara. Hal itu dikemukakan pula oleh Henry Campbell Black,11 yang mengartikan korupsi sebagai: "an act done with an intent to give some advantage inconsistent with official duty and the rights of others". (sesuatu perbuatan yang dilakukan dengan maksud untuk memberikan suatu keuntungan yang tidak sesuai dengan kewajiban resmi dan hak-hak dari pihak lain). Termasuk pula dalam pengertian "corruption" menurut Black adalah, perbuatan seorang pejabat yang secara melanggar hukum menggunakan jabatannya untuk mendapatkan suatu keuntungan yang berlawanan dengan kewajibannya.

${ }^{11}$ Henry Compbell Black, Black's Law Dictionary With Pronounciations, (St. Paul, Minn: West Publishing Co., 1983), hlm. 182 
Sedangkan menurut Sudarto, istilah korupsi berasal dari perkataan "corruption", yang berarti kerusakan. Disamping itu perkataan korupsi dipakai pula untuk menunjuk keadaan atau perbuatan yang busuk. Korupsi banyak disangkutkan kepada ketidakjujuran seseorang dalam bidang keuangan. ${ }^{12}$

Jadi korupsi jelas masuk kategori kejahatan, dengan mengacu kepada:

1. Pelaku yang terlibat dalam korupsi terdapat dalam kalangan pemerintah (pegawai negeri), swasta (pengusaha) maupun politik (politisi)

2. Berperilaku memperkaya diri atau yang berdekatan dengannya atau merangsang orang lain memperkaya diri

3. Cara yang dipakai tidak wajar dan tidak legal dengan menyalahgunakan kedudukannya.

Perbuatan korupsi harus memenuhi 4 (empat) unsur: ${ }^{13}$

12 Sudarto, Hukum dan Hukum Pidana, (Bandung: Penerbit Alumni, 1986), hlm. 42
1. Niat melakukan korupsi (desire to $a c t$ ): unsur ini berada didalam diri seseorang, dibentuk dalam waktu yang panjang dimulai sejak kecil. Ini sangat berkaitan dengan tiga macam teori tentang mengapa seseorang menjadi penjahat. Pertama, penjahat itu dilahirkan (the born criminal). Ini disebut juga teori bakat, yaitu seseorang sejak lahirnya telah memiliki sifat jahat. Kedua, penjahat yang terbentuk oleh lingkungan. Anak yang lahir dari lingkungan baikbaik akan jahat apabila berada dalam lingkungan penjahat. Ini biasanya disebut teori tabularasa, bahwa seseorang dilahirkan kedunia dalam keadaan bersih ibarat kertas putih, selanjutnya tergantung lingkungan yang membuatnya menjadi berwarna. Itulah sebabnya di beberapa negara maju, penjahat pemula tak dimasukkan kedalam penjara agar tidak bertambah jahat. Ketiga, teori campuran antara bakat dan lingkungan.

13 Bibit S. Riyanto, Koruptor Go To Hell: Mengupas Anatomi Korupsi Di Indonesia, (Bandung: Mizan Media Utama, 2009), hlm. 14-20 
2. Kemampuan untuk berbuat

berhubungan dengan kekuasakorupsi (ability to act): faktor ini senyatanya dapat disubtitusikan melalui penggunaan orang lain yang memiliki kemampuan yang diperlukan untuk berbuat jahat. Misalnya dengan jalan disewa, dipaksa atau dijanjikan sesuatu yang menarik apabila yang bersangkutan mau melakukan pekerjaan itu dengan menggunakan keahlian, kemampuan, atau kewenangan yang dimilikinya.

3. Peluang atau kesempatan untuk melakukan korupsi (opportunity to do corruption): ini dimiliki oleh orang memiliki kewenangan pada setiap jenjang kekuasaan. Peluang akan menjadi makin besar apabila:

a. Ketentuan yang berlaku sangat longgar dalam arti dapat memberi peluang melakukan korupsi

b. Diawaki oleh pejabat yang koruptif

c. Ada sesuatu yang dikorupsi

d. Orang-orang yang berhubungan dengan kekuasaan bisa menerima kondisi koruptif sebagai prasyarat untuk

4. Target atau adanya sasaran yang bisa dikorupsi (suitable target): unsur ini tidak dapat disubtitusikan, tapi dapat diciptakan oleh sipemilik kewenangan atau kekuasaan. Unsur ini dapat dilakukan sendiri atau bersama-sama dengan orang lain. Misalnya, kewenangan menentukan anggaran pendapatan dan belanja. Didalam menentukan program dan besaran anggaran terjadi negosiasi (lobby), antara pembela dan penyidik untuk penentuan pasal yang dilanggar pelaku, pembela dengan penuntut umum untuk menentukan dakwaan, antara pengacara dan hakim untuk menentukan putusan, antara panitia dan peserta tender suatu proyek yang ditenderkan, antara bawahan dan atasan agar mendapatkan promosi, antara 
peminta izin dan si pembuat izin, atau antara calon pejabat dan pemilih, dan sebagainya.

Perkembangan korupsi sampai saat ini sudah merupakan akibat dari sistem penyelenggaraan pemerintahan yang tidak tertata secara tertib dan tidak terawasi secara baik, karena landasan hukum yang dipergunakan juga mengandung banyak kelemahan dalam implementasinya. Dalam upaya untuk mempercepat tercapainya kesejahteraan sosial sebagaimana diamanatkan oleh Pembukaan UUD 1945 perlu adanya usaha untuk mempercepat pemberantasan korupsi, melalui implementasi undang-undang korupsi terhadap pelaku tindak pidana korupsi. ${ }^{14}$

\section{Tipologi Korupsi}

Pengertian korupsi secara yuridis, baik arti maupun jenisnya telah dirumuskan, di dalam UndangUndang Nomor 31 Tahun 1999 jo Undang-Undang Nomor 20 Tahun

\footnotetext{
14 Muhammad Nur, Kebijakan Hukum Pidana Terhadap Pemberantasan Tindak Pidana Korupsi, Dalam Jurnal Reusam Fakultas Hukum Universitas Malikussaleh, Vol. 1 No. 2 November 2013, hlm. 73

15 Setyo Utomo, Makalah yang disampaikan dalam Seminar Nasional Fakultas Hukum Universitas Indonesia
}

2001 tentang Pemberantasan Tindak Pidana Korupsi dan undang-undang sebelumnya, yaitu Undang-Undang Nomor 3 Tahun 1971. Dalam pengertian yuridis, pengertian korupsi tidak hanya terbatas kepada perbuatan yang memenuhi rumusan delik dapat merugikan keuangan negara atau perekonomian negara, tetapi meliputi juga perbuatanperbuatan yang memenuhi rumusan delik, yang merugikan masyarakat atau orang perseorangan. Dari 7 (tujuh) kelompok delik di tindak pidana korupsi, hanya 1 (satu) kelompok saja yang memuat unsur merugikan negara diatur di dalam 2 pasal yaitu pasal 2 dan 3.15

Oleh karena itu, rumusannya dapat dikelompokkan sebagai berikut

\section{Kerugian Keuangan Negara ;}

- Pasal 2

- Pasal 3

\section{Suap - Menyuap ;}

- Pasal 5 Ayat (1) huruf a

- Pasal 5 Ayat (1) huruf b

- Pasal 13

- Pasal 5 Ayat (2)

bekerja sama dengan Ikatan Nasional Konsultan Indonesia (INKINDO) tentang "Permasalahan Hukum Pada Pelaksanaan Kontrak Jasa Konsultasi dan Pencegahan Korupsi di Lingkungan Instansi Pemerintah", yang diselenggarakan di Balai Sidang Djokosoetono Gedung F Lantai 2 FH-UI Depok, Selasa 22 Juni 2010 
- Pasal 12 huruf a

- Pasal 12 huruf b

- Pasal 11

- Pasal 6 Ayat (1) huruf a

- Pasal 6 Ayat (1) huruf b

- Pasal 6 Ayat (2)

- Pasal 12 huruf c

- Pasal 12 huruf d

\section{Penggelapan Dalam Jabatan ;}

- $\quad$ Pasal 8

- Pasal 9

- Pasal 10 huruf a

- Pasal 10 huruf b

- Pasal 10 huruf c

\section{Pemerasan;}

- Pasal 12 huruf e

- Pasal 12 huruf g

- Pasal 12 huruf f

5. Perbuatan Curang ;

- Pasal 7 Ayat (1) hurufa

- Pasal 7 Ayat (1) huruf b

- Pasal 7 Ayat (1) huruf c

- Pasal 7 Ayat (1) huruf d

- Pasal 7 Ayat (2)

- Pasal 12 huruf h

6. Benturan Kepentingan Dalam Pengadaan ;

- Pasal 12 huruf $i$

\section{Gratifikasi ;}

- Pasal 12 B jo. Pasal 12 C

\section{Tindak Pidana Lain yang Berkaitan Dengan Tindak Pidana Korupsi:}

Tindak pidana lain yang berkaitan dengan tindak pidana korupsi tertuang dalam Pasal 21, 22, dan 24 Bab III UU No. 31 Tahun 1999 jo. UU No. 20 Tahun 2001 tentang Pemberantasan Tindak Pidana Korupsi yang terdiri dari:
1. Pasal 21 : Merintangi Proses Pemeriksaan Perkara Korupsi

2. Pasal 22 jo Pasal 28 : Tidak Memberi Keterangan atau Memberi Keterangan Yang Tidak Benar

3. Pasal 22 jo Pasal 29 : Bank Yang Tidak Memberikan Rekening Tersangka

4. Pasal 22 jo Pasal 35 : Saksi atau Ahli Yang Tidak Memberi Keterangan atau Memberi Keterangan Palsu

5. Pasal 22 jo Pasal 36 : Orang Yang Memegang Rahasia Jabatan Tidak Memberikan Keterangan atau Memberi Keterangan Palsu

6. Pasal 24 jo Pasal 31 : Saksi Yang Membuka Identitas Pelapor.

Terkait dengan pemberantasan korupsi, dalam praktek salah satu unsur penting yang harus dapat dibuktikan agar dapat dikualifikasi sebagai tindak pidana korupsi adalah adanya "unsur dapat merugikan keuangan negara atau perekonomian negara". Unsur kerugian negara sering menjadi polemik karena memiliki pengertian yang dapat dilihat dari beberapa perspektif hukum, yaitu berdasarkan perspektif hukum administrasi negara, hukum perdata 
dan hukum pidana, yang lebih lanjut akan diuraikan sebagai berikut: ${ }^{16}$

1. Pengertian kerugian negara berdasarkan perspektif hukum administrasi negara, dapat dilihat dari ketentuan Pasal 1 angka 22 Undang-Undang No. 1 Tahun 2004 tentang Perbendaharaan Negara, yaitu kekurangan uang, surat berharga, dan barang, yang nyata dan pasti jumlahnya sebagai akibat perbuatan melawan hukum baik sengaja maupun lalai. Rumusan pengertian kerugian negara dalam Undang-Undang No. 1 Tahun 2004 tentang Perbendaharaan Negara ini sama dengan rumusan pengertian kerugian negara sebagaimana diatur dalam Pasal 1 angka 15 UndangUndang No. 15 Tahun 2006 tentang Badan Pemeriksa Keuangan.

2. Pengertian kerugian negara berdasarkan perspektif hukum perdata terkait dengan pengertian keuangan negara yang dikelola oleh perusahaan negara/perusahaan daerah sebagaimana diatur dalam Undang-Undang No. 40 Tahun 2007 tentang Perseroan Terbatas dan Undang-Undang No. 19 Tahun 2003 tentang Badan Usaha Milik Negara. Jadi kerugian negara disini adalah berkurangnya Kekayaan Negara/Kekayaan Daerah yang dikelola sendiri atau oleh pihak lain berupa uang, surat berharga atau saham, piutang, barang, serta hak-hak lain yang dapat dinilai dengan uang, termasuk kekayaan yang dipisahkan pada perusahaan negara/perusahaan daerah yang disebabkan oleh perbuatan yang melanggar norma atau aturan yang telah ditetapkan berdasarkan ketentuan yang berlaku dalam Undang-Undang No. 40 Tahun 2007 tentang Perseoan Terbatas dan Undang-Undang No. 19 Tahun 2003 tentang Badan Usaha Milik Negara.

3. Pengertian kerugian negara berdasarkan perspektif hukum pidana adalah suatu perbuatan

\footnotetext{
16 Setyo Utomo, Ibid.
} 
yang menyimpang terhadap penggunaan dan pengelolaan keuangan negara sehingga dapat dikualifikasikan sebagai perbuatan merugikan negara atau dapat merugikan negara sebagai tindak pidana korupsi, dengan pemenuhan unsurunsur: pertama, perbuatan tersebut merupakan perbuatan melawan hukum, baik dalam pengertian formil maupun materil atau penyalahgunaan wewenang, kesempatan atau sarana yang ada padanya, dan kedua, para pihak ada yang diperkaya dan diuntungkan, baik si pelaku sendiri, orang lain atau korporasi (Pasal 2 dan Pasal 3 Undang-Undang No. 31 Tahun 1999 jo. Undang-Undang No. 20 Tahun 2001).

Jika mengacu pada pengertian kerugian negara berdasarkan perspektif hukum administrasi negara maka pengertiannya disini adalah pengertian kerugian negara yang memaknai pengertian keuangan negara, sehingga berbeda dengan kerugian negara yang terdapat dalam Undang-Undang No. 31 Tahun 1999 jo. Undang-Undang No. 20 Tahun 2001 tentang Pemberantasan Tindak Pidana Korupsi, yang merupakan pengertian yang spesifik dan merupakan lex specialias derogat legi generalis sistematis, yaitu meskipun sama-sama bersifat khusus, tetapi yang mendominasi adalah lingkup kepentingannya dalam hal ini adalah pidana. Tegasnya penerapannya harus melihat kepada lingkup permasalahannya, jika menyangkut masalah pidana maka yang diberlakukan adalah hukum pidana, sehingga mengesampingkan hukum perdata dan hukum administrasi negara. Sebagai contoh dalam praktek selama ini dalam hal penerapan pengertian Pegawai Negeri, walaupun diatur di dalam Undang-Undang Kepegawaian Nomor 8 Tahun 1974 jo. UU No. 43 Tahun 1999, tetapi yang digunakan dalam tindak pidana korupsi adalah pengertian pegawai negeri di dalam Undang-Undang No. 31 Tahun 1999 jo. Undang-Undang jo. No. 20 Tahun 2001 tentang Pemberantasan Tinak Pidana Korupsi, bahkan pengertian sesama hukum pidana termuat dalam KUHP juga diabaikan.

Mengenai unsur "merugikan keuangan negara" aparat penegak hukum bekerjasama dengan instansi 
terkait yaittu BPK atau BPKP untuk menghitung kerugian negara. Kewenangan BPK atau BPKP dalam melakukan audit adalah dalam zona accounting, sehingga tidak perlu jauh sampai mencari adanya perbuatan melawan hukum atau tidak, karena itu merupakan kewenangan Penyidik dan Penuntut Umum. Pengertian merugikan negara di lingkungan Departemen dapat diartikan, bahwa anggaran yang telah ditetapkan tidak dipergunakan sesuai dengan peruntukannya atau terjadi penyimpangan.

Selain menyangkut pengertian keuangan negara, dalam praktek sering menjadi polemik adalah pengertian unsur melawan hukum, tetapi dengan adanya putusan Mahkamah Konstitusi Nomor: 003/PUU-IV/2006 tanggal 25 Juli 2006 yang meniadakan berlakunya penjelasan Pasal 2 ayat (1) UndangUndang No. 31 Tahun 1999, sehingga perbuatan melawan hukum dalam arti materiil yaitu perbuatan yang dianggap tercela, tidak sesuai dengan rasa keadilan atau norma-norma kehidupan sosial masyarakat, dinyatakan tidak mempunyai kekuatan hukum yang mengikat, karena pengertian melawan hukum secara materiil dipandang bertentangan dengan Undang-Undang Dasar Negara Republik Indonesia Tahun 1945, maka seharusnya polemik tentang pengertian melawan hukum tersebut berakhir. ${ }^{17}$

Pengertian "melawan hukum" sering dirancukan dengan pengertian "menyalahgunakan wewenang" padahal dua hal itu jelas berbeda, meskipun hakekatnya penyalahgunaan wewenang tersebut adalah juga melawan hukum. Melawan hukum adalah perbuatan yang bertentangan dengan peraturan perundang-undangan yang bisa dilakukan oleh setiap orang. Sedangkan menyalahgunakan wewenang adalah juga perbuatan yang bertentangan dengan peraturan perundang-undangan, hanya bisa dilakukan oleh seseorang yang mempunyai kewenangan dan kapasitas tertentu yang terkait dengan jabatannya terkait dengan prosedural. Menyalahgunakan kewenangan, kesempatan, atau sarana yang ada terkait dengan posisinya selaku penyelenggara negara atau pegawai

\footnotetext{
17 Setyo Utomo, Ibid.
} 
negeri di institusi itu secara salah, dapat disebut sebagai "misbruik van gesag atau van bevoeg", menyalahgunakan kewenangan, kesempatan, atau sarana yang ada padanya karena jabatan atau kedudukan dan kewenangan tersebut digunakan tidak sesuai dengan tugas jabatannya.

Unsur "memperkaya diri atau orang lain atau suatu korporasi" (vide Pasal 2 ayat (1) UU No. 31 Tahun 1999 jo. UU No. 20 Tahun 2001) dan unsur "dengan tujuan menguntungkan diri sendiri atau orang lain atau suatu korporasi " (vide Pasal 3 UU No. 31 Tahun 1999 jo.UU No. 20 Tahun 2001), merupakan unsur yang besifat alternatif sehingga tiak perlu pelaku tindak pidana korupsi harus menikmati sendiri uang hasil tindak pidana korupsi, cukup si pelaku memperkaya orang lain atau menguntungkan orang lain. Secara teoritis, unsur "memperkaya diri" diartikan bertambah kekayaannya atau pelaku berpola hidup mewah tanpa hak di dalam menikmati hasil korupsinya dalam kehidupan sehariharinya, tetapi dalam praktek setiap tindakan dari subyek hukum yang menimbulkan kerugian negara, baik itu karena tanda tangan, pemindahan buku, mengambil, menyerahkan, menyimpan diluar prosedur yang berlaku, maka perbuatan tersebut dapat dipandang sebagai perbuatan memperkaya diri. Sedangkan unsur "menguntungkan diri atau orang lain atau suatu korporasi", artinya pelaku memperoleh fasilitas atau kemudahan sebagai akibat dari perbuatan menyalahgunakan wewenang atau prosedur.

Kemudian dalam pembuktian unsur "dapat merugikan keuangan negara atau perekonomian negara", sering terjadi perbedaan persepsi adalah menyangkut penafsiran kata "dapat " yang oleh sebagian kalangan dipandang sebagai potensi, karena mengacu kepada "cukup dengan dipenuhinya unsur-unsur perbuatan yang dirumuskan bukan dengan timbulnya akibat" (penjelasan pasal 2 ayat(1) Undang-Undang Nomor 31 Tahun 1999 tentang Pemberantasan Tindak Pidana Korupsi), jika menilik syaratnya penempatan kata dapat tersebut, sebenarnya oleh pembuat undang-undang dimaksudkan hanya untuk menempatkan kedua delik tersebut, dari delik formil materiil menjadi delik formil dengan meninjau filosofi dari delik pencurian (Pasal 362 KUHP) dan penggelapan (Pasal 372 
KUHP). Dalam pengertian perbuatan tersebut telah selesai (voltoid) kalau barang atau uang tersebut telah berpindah dari tempatnya atau tujuannya semula yang dilakukan secara melawan hukum. Terhadap delik-delik tertentu dari undangundang korupsi memang sejalan dengan pemahaman tersebut, seperti penyuapan, pemerasan atau penggelapan dalam jabatan, tetapi terhadap delik yang mengandung unsur merugikan negara kata "dapat" tidak sekedar potensi yang abstrak, tetapi harus konkrit dan itu lambat atau cepat harus riil terjadi. Oleh karena itu, jika kata dapat merugikan keuangan negara tersebut berupa potensi, maka sifatnya hanya asumsi dan hal itu bertentangan dengan azas legalitas yang salah satunya mensyaratkan adanya kepastian hukum. ${ }^{18}$

Selanjutnya terkait dengan pengertian penyuapan, penyuapan terdiri dari 2 jenis. Pertama adalah penyuap aktif, yaitu pihak yang memberikan atau menjanjikan sesuatu, baik berupa uang atau barang. Penyuapan ini terkait erat dengan sikap batin subjek hukum berupa niat (oogmerk) yang bertujuan untuk menggerakkan seorang pejabat penyelenggara negara atau pegawai negeri agar ia dalam jabatannya berbuat atau tidak berbuat sesuatu yang bertentangan dengan kewajibannya. Dari pemberian hadiah atau janji tersebut, berarti subjek hukum mengetahui tujuan yang terselubung yang diinginkannya, yang didorong oleh kepentingan pribadi, agar penyelenggara negara atau pegawai negeri yang akan diberi hadiah atau janji berbuat atau tidak berbuat sesuatu dalam jabatan yang bertentangan dengan kewajibannya. Meskipun pejabat yang bersangkutan menolak pemberian atau janji tersebut, perbuatan subjek hukum sudah memenuhi rumusan delik dan dapat dijerat oleh delik penyuapan aktif, mengingat perbuatannya sudah selesai (voltoid).

Kemudian kedua adalah penyuapan pasif, pihak yang menerima pemberian atau janji baik berupa uang maupun barang. Apabila pegawai negeri tersebut menerima pemberian atau janji dalam pasl ini, berarti pegawai negeri/penyelenggara negara dimaksud akan menanggung

\footnotetext{
18 Setyo Utomo, Ibid.
} 
beban moril untuk memenuhi permintaan pihak yang memberi atau yang menjanjikan tersebut. ${ }^{19}$

Selain penyuapan aktif dan pasif tersebut yang lazim juga terjadi terkait dengan praktek korupsi adalah penggelapan dan pemerasan. Larangan yang terkait dengan tindak pidana korupsi jenis ini adalah perbuatan menggelapkan uang atau surat berharga yang menjadi tanggungjawab jabatannya atau membiarkan uang atau surat berharga tersebut diambil atau digelapkan orang lain.

Sedangkan yang dimaksudkan dengan pemerasan terkait dengan tindak pidana korupsi adalah pemerasan dalam jabatan (knevelarij) dan salah satu unsurnya adalah memaksa seseorang memberikan sesuatu, membayar, atau menerima pembayaran dengan potongan, atau untuk mengerjakan sesuatu bagi dirinya sendiri (Pasal 12 huruf e dan $\mathrm{f}$ Undang-Undang Nomor 31 Tahun 1999 jo. Undang-Undang Nomor 20 Tahun 2001). Bentuk pemaksaan disini lebih ditujukan secara psikis

\footnotetext{
19 Marwan Effendy, Tipologi Kejahatan Perbankan dari Perspektif Hukum Pidana, (Jakarta: Sumber Ilmu Jaya, Cet. I, 2005), hlm. 126.
}

sebagai akibat yang ditimbulkan dari kewenangan yang melekat pada diri pejabat yang bersangkutan. Kehendak untuk memaksakan kepentingan pribadinya harus dirasakan oleh orang yang menjadi obyeknya. ${ }^{20}$

$$
\text { Pegawai negeri atau }
$$
penyelenggara negara turut serta dalam pengadaan yang diurusnya adalah korupsi, ini sesuai dengan Pasal 12 huruf i Undang-Undang 31 Tahun 1999 jo. Undang-Undang Nomor 20 Tahun 2001 "Pegawai negeri atau penyelenggara negara baik langsung maupun tidak langsung dengan sengaja turut serta dalam pemborongan, pengadaan, atau persewaan, yang pada saat dilakukan perbuatan, untuk seluruh atau sebagian ditugaskan untuk mengurus atau mengawasinya".

Istilah pegawai negeri yang sebagai subjek tindak pidana korupsi juga mengalami perluasan makna, dimana pengertian pegawai negeri dalam Undang-Undang Nomor 31 Tahun 1999 sudah sangat luas. Kebijakan kriminal ini ditempuh untuk menjerat mereka yang mengelola

20 P.A.F. Lamintang, et.al, Hukum Pidana Indonesia, (Sinar Baru, Bandung, cet. Ke-III, 1990), hlm. 231-234 
keuangan negara. Dalam Pasal 1 sub 2 ditegaskan bahwa: Pegawai negeri adalah meliputi;

a. Pegawai negeri sebagaimana dimaksud dalam undangundang tentang kepegawaian;

b. Pegawai negeri sebagaimana dimaksud dalam Kitab Undang-Undang Hukum Pidana;

c. orang yang menerima gaji atau upah dari keuangan negara atau daerah;

d. Orang yang menerima gaji atau upah dari suatu korporasi yang menerima bantuan dari keuangan negara atau daerah, atau;

e. orang yang menerima gaji atau upah dari korporasi lain yang mempergunakan modal atau fasilitas dari negara atau masyarakat.

Sedangkan dengan UndangUndang Nomor 20 Tahun 2001 juga memperluas pelaku tindak pidana korupsi, yaitu meliputi penyelenggara negara, pemborong, ahli bangunan, orang yang menjalankan jabatan umum terus-menerus atau sementara waktu, Hakim dan Advokat. ${ }^{21}$

Disamping itu, perlu juga mendapat perhatian adalah masalah gratifikasi. Gratifikasi ini dengan berlakunya Undang-Undang Nomor 20 Tahun 2001 secara tegas dilarang. Pengertiannya dalam arti luas meliputi pemberian uang, barang, rabat (discount), komisi, pinjaman tanpa bunga, tiket perjalanan, fasilitas penginapan, perjalanan sosialisasi, pengobatan cuma-cuma atau fasilitas lainnya.

Melihat pengertian diatas bermakna bahwa gratifikasi bukan merupakan perbuatan pidana, dikatakan gratifikasi apabila yang kegiatan tersebut berhubungan dengan jabatan dan berlawanan dengan kewajiban atau tugasnya. Ketentuan diatas tidak mencantumkannya mengenai pemberi gratifikasi. Padahal pemberi gratifikasi dan penerima gratifikasi dapat dikategorikan sebagai pesuap aktif dan pesuap pasif. Menurut Yenti Ganarsih (Pakar Tindak Pidana

21 Darwan Prinst, Pemberantasan Tindak Pidana Korupsi, (Bandung: Citra Aditya Bhakti, 2002), hlm. 21 
Pencucian Uang) mengatakan bahwa harus ada tiga unsur pelaku gratikasi seksual yaitu, orang yang memberi gratifikasi, pejabat yang disuap dan pelayan seksualnya sendiri. Biasanya, pelaku prostitusi dalam perkara ini tidak pernah tersentuh. ${ }^{22}$

Hal tersebut perlu dipahami secara benar karena akan berkaitan dengan masalah pengumpulan alat bukti dan pembuktiannya di depan persidangan. Pengertian alat bukti petunjuk tidak saja dapat diperoleh dari keterangan saksi, keterangan terdakwa dan surat-surat sebagaimana dirumuskan dalam KUHAP, tetapi juga dapat diperoleh melalui alat bukti lain menurut pasal 26 a Undang-Undang Nomor 20 Tahun 2001 yang berupa informasi yang diucapkan, dikirim, diterima, atau disimpan secara elektronik dengan alat optik atau yang serupa dengan itu, atau melalui dokumen berupa rekaman data atau informasi yang dapat dilihat, dibaca, dan atau didengar yang dapat dikeluarkan dengan atau tanpa bantuan suatu sarana, baik yang tertuang diatas

22 Koran Sindo, Tgl. 9 Januari 2013, Lihat Juga, Yusrizal, Menyoal Gratifikasi Seks, Harian Serambi Indonesia Tgl. 14 Pebruari 2013 Sebagaimana Juga Dimuat kertas atau benda lain maupun yang terekam secara elektronik berupa tulisan, suara, gambar, peta, rancangan, foto, huruf, tanda, angka atau perforasi yang memiliki makna. Rumusan yang demikian ini, tidak saja memperluas cakupan pengertian tindak pidana korupsi, tetapi juga memudahkan di dalam pembuktiannya.

Adapun unsur "yang dapat merugikan keuangan negara" dalam praktik menimbulkan silang pendapat, apakah delik yang bersangkutan merupakan delik formal atau delik materiil. Untuk lebih mengefektifkan pemberantasan korupsi, dalam penjelasan umum Undang-Undang Nomor 31 Tahun 1999 ditegaskan bahwa dalam undang-undang ini, tindak pidana korupsi dirumuskan secara tegas sebagai tindak pidana formil. Hal ini sangat penting untuk pembuktian. Dengan rumusan secara formil yang dianut dalam UndangUndang ini, meskipun hasil korupsi telah dikembalikan kepada negara, pelaku tindak pidana korupsi tetap diajukan ke pengadilan. Menurut

Dalam Desain Hukum Newsletter Komisi Hukum Nasional, Vol. 14 No. 3, April 2014 hlm. 24 
Romli Atmasasmita, Undang-Undang ini telah merumuskan tindak pidana korupsi sebagai delik formil, bukan delik materil sehingga pengembalian keuangan negara tidak menghapuskan penuntutan terhadap terdakwa, melainkan hanya faktor yang meringankan pidana ${ }^{23}$.

\section{Perihal Hukum Acara Dalam Penanganan Perkara Korupsi}

Pada dasarnya konsep Negara Hukum merupakan bagian yang tidak terpisahkan dari doktrin Rule of law dimana dari beberapa doktrin dapat disimpulkan bahwa semua tindakan penegakan hukum pidana (termasuk) Pemerintah harus berdasarkan atas hukum dan adanya jaminan terhadap hak-hak asasi manusia antara lain Asas Praduga tidak bersalah (presumption of innocence) dan Asas Legalitas (principle of legality). Asas Praduga tidak bersalah dan asas legalitas merupakan bagian dari Hukum Pidana Formil dan Hukum Pidana Materiil yang merupakan Sub sistem dari Sistem Hukum Pidana. Marc Ancel menyebutkan sistem hukum pidana abad XX masih harus diciptakan. Sistem demikian hanya

23 Romli Atmasasmita, Sekitar Masalah Korupsi, (Bandung: Mandar Maju, 2004), hal. 19 dapat disusun dan disempurnakan oleh usaha bersama semua orang yang beritikad baik dan juga oleh semua ahli di bidang ilmu-ilmu sosial. ${ }^{24}$ Konsep yang paling rawan adalah jika penyidik dalam menetapkan tersangka korupsi tidak berdasarkan hukum dan fakta hukum yang memadai atau bahkan sarat rekayasa, sehingga pada akhirnya membuat proses penegakan hukum tidak berjalan.

Tekad untuk memberantas korupsi tidak bisa hanya melalui peraturan perundang-undangan semata, melainkan itikad baik dari penegak hukum. Itikad baik harus diwujudkan berupa perbuatan yang sesuai dengan prosedur hukum. Sudah saatnya menyatakan bahwa hukum itu harus berhati nurani, hukum diciptakan dan ada untuk mengabdi pada masyarakat, bernurani terhadap kebenaran-kebenaran, keadilan dalam pemberantasan korupsi. Peranan pejabat penegak hukum dalam memberantas korupsi sangat dipengaruhi oleh moral dan etika yang berintegritas (pembangunan kecerdasan spiritual) dengan pemahaman yang mapan akan menghasilkan

${ }^{24}$ Marc Ancel, Social Defence, A Modern Approach to Criminal Problems (London, Routledge \& Kegan Paul, 1965), hlm. 4-5 
budaya hukum atas pembersihan korupsi tersebut. ${ }^{25}$

Tersangka adalah seorang yang karena perbuatannya atau keadaannya, berdasarkan bukti permulaan patut diduga sebagai pelaku tindak pidana (Pasal 1 butir 14 KUHAP). Selanjutnya Pasal 17 KUHAP menyebutkan, "Perintah penangkapan dilakukan terhadap seorang yang diduga keras melakukan tindak pidana berdasarkan bukti permulaan yang cukup".

Berdasarkan kedua pasal itu jelas terlihat perbedaannya bahwa untuk menetapkan seseorang sebagai tersangka diperlukan bukti permulaan. Bukti di sini tidak hanya sebatas alat bukti sebagaimana dimaksud dalam Pasal 184 KUHAP, yakni keterangan saksi, keterangan ahli, surat, keterangan terdakwa, dan petunjuk. Namun, bukti di sini juga dapat meliputi barang bukti yang secara garis besar dibagi menjadi dua, yaitu barang-barang yang digunakan untuk melakukan kejahatan (corpus delicti) dan barang-barang hasil

25 Yusrizal, Kapita Selekta Hukum Pidana dan Kriminologi, (Jakarta: PT. Sofmedia, 2012), hlm. 149

26 Novianti, Penangkapan dan Penetapan Tersangka Kasus Dugaan Suap kejahatan (instrumenta delicti).

Sementara untuk melakukan penangkapan terhadap seorang tersangka diperlukan bukti permulaan yang cukup. Kata-kata "bukti permulaan yang cukup" berdasarkan tolok ukur pembuktian dalam doktrin hukum merujuk pada bewijs minimum atau bukti minimum yang diperlukan untuk memproses seseorang dalam perkara pidana, yakni dua alat bukti sebagaimana yang ditemukan dalam penyelidikan maupun penyidikan. ${ }^{26}$

Penyidikan yang dilakukan tersebut didahului dengan pemberitahuan kepada penutut umum bahwa penyidikan terhadap suatu peristiwa pidana telah mulai dilakukan. Secara formal pemberitahuan tersebut disampaikan melalui mekanisme Surat Pemberitahuan Dimulainya Penyidikan (SPDP). Hal tersebut diatur dalam ketentuan Pasal 109 KUHAP. Namun kekurangan yang dirasa sangat menghambat adalah tidak ada ketegasan dari ketentuan tersebut kapan waktunya penyidikan harus

Impor Daging Sapi, Dimuat Info Singkat Hukum, Vol. V No. 03/I/P3DI/Pebruari/2013, hlm. 2-3 
diberitahukan kepada Penuntut Umum.

Asas Praduga Tak Bersalah atau presumption of innocence dijumpai dalam penjelasan umum butir 3 huruf c KUHAP. Dicantumkannya asas praduga tak bersalah dalam penjelasan KUHAP dapat disimpulkan bahwa pembuat Undang-Undang telah menetapkannya sebagai asas hukum yang melandasi KUHAP dan penegakkan hukum. Asas Praduga Tak Bersalah ditinjau dari segi yuridis atau dari tekhnis penyidikan dinamakan akusator atau accusatory procedure, prinsip akusatur menempatkan kedudukan tersangka dalam setiap tingkat pemeriksaan yaitu sebagai subjek bukan sebagai objek pemeriksaan karena itu tersangka harus didudukkan dan diperlakukan dalam kedudukan manusia yang mempunyai martabat dan harga diri, sedangkan yang menjadi objek pemeriksaan adalah kesalahan (tindak pidana) yang dilakukan oleh tersangka, kearah itulah pemeriksaan atau penyidikan dilakukan. 27

27 M. Yahya Harahap, Pembahasan Permasalahan dan Penerapan KUHAP: Penyidikan dan Penuntutan, (Jakarta: Sinar Grafika, 2006), hlm. 40
Perlindungan hak-hak tersangka diberikan dalam kerangka memperlakukan seseorang tersangka sebagai orang yang dianggap tidak bersalah selama belum ada bukti yang kuat dan putusan pengadilan yang mempunyai kekuatan hukum tetap. Pada hakekatnya hak tersangka/ terdakwa adalah hak yang diperoleh selama proses penyidikan atau tahap pemeriksaan berdasarkan ketentuan Undang-Undang Nomor 8 Tahun 1981 atau yang lebih dikenal dengan Kitab Undang-Undang Hukum Acara Pidana (KUHAP). Perlindungan hak tersangka/terdakwa tidak terlepas dari pelaksanaan asas-asas dalam hukum pidana. Sebagaimana adanya hak prioritas penyelesaian perkara (Pasal 50 KUHAP).28

Pada pemeriksaan tersangka, penyidik wajib memperhatikan segisegi manusiawi, karena tersangka bukanlah sebagai obyek tetapi sebagai subyek yang mempunyai hak dan kewajiban. Penyidikan sebagai usaha pertama untuk mengumpulkan bukti guna membuat terang suatu tindak

28 Bambang Tri Bawono, Tinjauan Yuridis Hak-hak Tersangka Dalam Pemeriksaan Pendahuluan, Dalam Jurnal Hukum Vol XXVI, No. 2, Agustus 2011, hlm. 558-559 
pidana sepenuhnya menjadi tanggung jawab kepolisian. Oleh karena itu, terhadap hasil pemeriksaan tersangka dan bahan pembuktian lainnya, sebelum diserahkan kepada penuntut umum, penyidik wajib secara obyektif menilai bahan pembuktian tersebut atas dasar kebenaran yang sejati mengingat pada asas-asas manusiawi. ${ }^{29}$

Berkaitan dengan saksi, menurut Pasal 1 angka 26 Kitab Undang-Undang Hukum Acara Pidana ("KUHAP"), adalah orang yang dapat memberikan keterangan guna kepentingan penyidikan, penuntutan dan peradilan tentang suatu perkara pidana yang ia dengar sendiri, ia lihat sendiri dan ia alami sendiri. Pengertian tersebut berdasarkan Putusan Mahkamah Konstitusi Nomor 65/PUU-VIII/2010 Pengujian Undang-Undang Nomor 8 Tahun 1981 Tentang Hukum Acara Pidana diperluas menjadi termasuk pula "orang yang dapat memberikan keterangan dalam rangka penyidikan, penuntutan, dan peradilan suatu tindak pidana yang tidak selalu ia dengar

${ }^{29}$ Ibid, hlm. 562 sendiri, ia lihat sendiri dan ia alami sendiri".

\section{Perluasan Praperadilan $^{30}$}

Kewenangan

Putusan bernomor 21/PUUXII/2014 yang salah satunya menguji ketentuan objek praperadilan. Mahkamah Konstitusi dalam putusannya menyatakan, dalam praperadilan, meski dibatasi secara limitatif dalam Pasal 1 angka 10 jo Pasal 77 huruf a KUHAP, akan tetapi penetapan tersangka adalah bagian dari proses penyidikan yang terbuka kemungkinan terdapat tindakan sewenang-wenang. "Sehingga sudah seharusnya penetapan tersangka menjadi bagian dari proses penyidikan yang dapat dimintakan perlindungan melalui pranata praperadilan".

Putusan itu juga merujuk pada putusan Mahkamah Konstitusi bernomor 65 /PUU-IX/2011 yang menghapus keberadaan Pasal 83 ayat (2) KUHAP. Dalam pertimbangan putusan itu, disebutkan sistem praperadilan sebagai salah satu mekanisme kontrol terhadap kemungkinan tindakan sewenangwenang oleh penyidik/penuntut

30 www. hukumonline.com Di akases Tgl 13 Mei 2015 
umum dalam melakukan penangkapan, penggeledahan, penyitaan, penyidikan, penuntutan, penghentian penyidikan dan penghentian penuntutan.

"Secara implisit, Mahkamah sesungguhnya telah menyatakan pendapatnya bahwa penggeledahan dan penyitaan bagian mekanisme kontrol terhadap kemungkinan tindakan sewenang-wenang dari penyidik/penuntut umum. Karenanya, keduanya termasuk dalam ruang lingkup praperadilan," oleh sebab itu penetapan tersangka saat ini sudah menjadi objek dalam pemeriksaan praperadilan yang akan dijadikan sebagai ujian apakah proses penetapan seseorang tersangka sudah memenuhi prosedur atau tidak.

\section{E. PENUTUP}

\section{Kesimpulan}

Berdasarkan pembahasan diatas dapat disimpulkan bahwa dalam menegakkan hukum (khsusnya pemberantasan korupsi) maka penggunaan hukum sebagai panglima seyogiyanya harus dikedepankan. Ini berarti bahwa setelah adanya alat bukti yang cukup dan sistem pemeriksaan yang fair barulah proses penegakan hukum mencerminkan rasa keadilan. Karena saat ini ada mekanisme baru dalam hukum acara yang berkaitan dengan praperadilan yang memungkinkan seseorang yang sudah ditetapkan sebagai tersangka bisa menguji kembali penetapan dirinya dipengadilan. Oleh sebab itu harus dipahami bahwa aparat penegak hukum harus jeli melihat masalah ini sebagai upaya pengawasan terhadap kebijakan yang telah diambil.

\section{Saran}

Proses penegakan hukum korupsi memang selayaknya menjadi perang bersama seluruh elemen bangsa. Namun, dalam pelaksanaannya harus mengedepankan prinsip-prinsip hukum yang berlaku secara universal. Semoga saja dalam penegakan hukum korupsi tidak adanya penetapan tersangka yang berkepenjangan, tanpa proses hukum, sehingga label tersangka bagi koruptor menjadi permasalahan tersendiri dalam kehidupan sosial.

\section{DAFTAR PUSTAKA}

Bambang Tri Bawono, Tinjauan Yuridis Hak-hak Tersangka Dalam Pemeriksaan Pendahuluan, Dalam Jurnal Hukum Vol. XXVI, No. 2, Agustus 2011 
Bibit S. Riyanto, Koruptor Go To Hell: Mengupas Anatomi Korupsi Di Indonesia, Bandung: Mizan Media Utama, 2009

Darwan Prinst, Pemberantasan Tindak Pidana Korupsi, Bandung: Citra Aditya Bhakti, 2002

Dani Krisnawati, dkk, Bunga Rampai Hukum Pidana Khusus, Jakarta: Pena, 2006

Henry Compbell Black, Black's Law Dictionary With Pronounciations, St. Paul, Minn: West Publishing Co., 1983

L.M Friedman, The Legal System: A Social Science Perspective, New York Russel Sage Foundation, 1975

Marc Ancel, Social Defence, A Modern Approach to Criminal Problems London, Routledge \& Kegan Paul, 1965

Moh. Hatta, Beberapa Masalah Penegakan Hukum Pidana Umum dan Pidana Khusus, Yogyakarta: Liberty Yogyakarta, 2009

Muhammad Nur, Kebijakan Hukum Pidana Terhadap Pemberantasan Tindak Pidana Korupsi, Dalam Jurnal Reusam Fakultas Hukum Universitas Malikussaleh, Vol. 1 No. 2 November 2013

Marwan Effendy, Tipologi Kejahatan Perbankan dari Perspektif Hukum Pidana, Jakarta: Sumber Ilmu Jaya, Cet. I, 2005

M. Yahya Harahap, Pembahasan Permasalahan dan Penerapan KUHAP: Penyidikan dan Penuntutan, Jakarta: Sinar Grafika, 2006

Novianti, Penangkapan dan Penetapan Tersangka Kasus Dugaan Suap Impor Daging Sapi, Dimuat Info
Singkat Hukum, Vol. V No. 03/I/P3DI/Pebruari/2013

P.A.F. Lamintang, et.al, Hukum Pidana Indonesia, Sinar Baru, Bandung, cet. Ke-III, 1990

Romli Atmasasmita, Sekitar Masalah Korupsi, Bandung: Mandar Maju, 2004

Satjipto Rahardjo, Penegakan Hukum Suatu Tinjauan Sosiologis, Yogyakarta: Genta Publishing, 2009

Setyo Utomo, Makalah yang disampaikan dalam Seminar Nasional Fakultas Hukum Universitas Indonesia bekerja sama dengan Ikatan Nasional Konsultan Indonesia (INKINDO) tentang "Permasalahan Hukum Pada Pelaksanaan Kontrak Jasa Konsultasi dan Pencegahan Korupsi di Lingkungan Instansi Pemerintah", yang diselenggarakan di Balai Sidang Djokosoetono Gedung F Lantai 2 FH-UI Depok, Selasa 22 Juni 2010

Sudarto, Hukum dan Hukum Pidana, Bandung: Penerbit Alumni, 1986

Teguh Prasetyo dan Abdul Halim Barkatullah, Politik Hukum Pidana Kajian Kebijakan Kriminalisasi dan Dekriminalisasi, (Yogyakarta: Pustaka Pelajar, 2005

Tb. Ronny Rahman Nitibaskara, Tegakkan Hukum Gunakan Hukum, Jakarta: Kompas, 2006

Yusrizal, Kapita Selekta Hukum Pidana dan Kriminologi, Jakarta: PT. Sofmedia, 2012

---------, Asas Legalitas Dalam Sistem Hukum Pidana Di Indonesia, Dalam Jurnal Reusam Fakultas Hukum Universitas Malikussaleh, Vol. 1 No. 2 November 2013 
------, Menyoal Gratifikasi Seks,

Desain Hukum Newsletter Komisi

Hukum Nasional, Vol. 14 No. 3,

April 2014

Jurnal Ilmu Hukum REUSAM: Volume IV Nomor 1 (Mei 2015) | 74 